УДК 330.341 .1

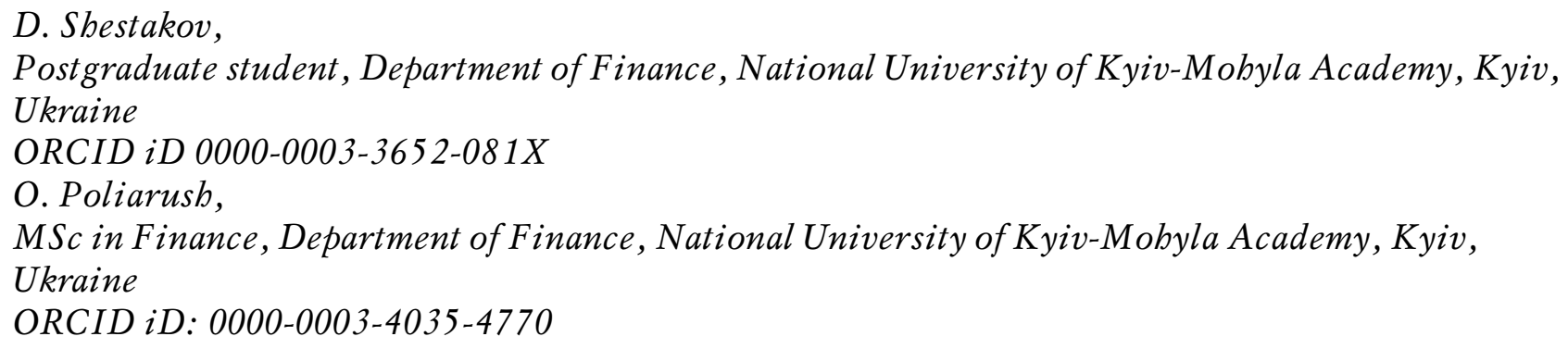

DOI: $10.32702 / 2306-6814.2019 .11 .66$

\title{
THE DEGREE OF INNOVATION: THROUGH INCREMENTAL TO RADICAL
}

\author{
А. Ю. Шестаков, \\ аспірант, кафедра фінансів, Факультет економічних наук, \\ Національний університет "Києво-Могилянська академія", м. Київ, Україна \\ О. С. Поляруш, \\ магістр, кафедра фінансів, Факультет економічних наук, \\ Національний університет "Києво-Могилянська академія", м. Київ, Україна
}

\section{СТУПІНЬ ІННОВАЦIÏ: ВIА ІНКРЕМЕНТНОÏ АО РААИКА}

Innovation is one of the most important forms of expanding the economic system 's capabilities and competitiveness in a modern, dynamic world. Since the beginning of the 20th century, the theory of innovation has been developing, changing, and improving significantly and many scientific papers have been created on the topic of types of innovation. However, even today, scientists are confused in basic concepts, replacing one with another and taking one for the other without proper and indepth terminology understanding. Although from innovation direction point of view, there is a clear distinction between types, some uncertainty in the levels (degrees) of innovations is present. For many years there have been many differences in the scientific literature, which significantly influenced both the in-depth understanding of the innovation concept and the quality of approaches to assessing the levels of innovation. The purpose of this paper is to in-depth review the literature on innovation types to identify approaches that emphasize the degree of innovation. We considered the different conclusions of the researchers step by step and argue that there is the problem of identifying one or another innovation in terms of its degree and find the disagreements in the scientific literature in basic concepts to understand high degree innovation. The most complete and extended definitions of incremental, semi-radical, radical, disruptive, and breakthrough innovation were proposed as well as Degree of Innovation matrix was created to clearly demonstrate the existing distinctive features of each individual degree of innovation. This paper contributes to the theoretical analysis of the impact of innovative knowledge, as well as broadens previously published scientific literature, analyzing its impact on understanding the types and degrees of innovation, as well as the relationships, characteristics and key differences between them. The results of the research is the conceptual basis supported by the scientific literature for the modern understanding of terminology in the field of innovation activities.

Інноваціяє однією з найважливіших форм розширення можливостей та конкурентоспроможності економічної системи у сучасномудинамічному світі. 3 початку ХХ ст. теорія інноваційної діяльності зазнала значного розвитку, змін та вдосконалення. Однак сьогодні науковий світ плутається в основних поняттях, замінюючи одне на інше без відповідного розуміння термінології. Хоча з точки зору інноваційного напряму є чітке розмежування типів, існує певна невизначеність у рівнях (ступенях) інновацій. Протягом багатьох років у науковій літературі було багато розбіжностей, що суттєво вплинуло як на глибинне розуміння концепції інновації, так і на 
якість підходів до оцінки ступенів інновацій. Широкий спектр наукових праць нерідко викручує терміни і ототожнює різні поняття інноваційних ступенів, особливо революційні (радикальні, руйнівні та проривні інновації). Оскільки науковий підхід цінується в сучасному світі, він зобов'язаний надати чітке й однозначне тлумачення основних понять у такій важливій для всебічного економічного розвитку сфері інноваційної діяльності. У роботі детально розглянуто різні наукові дослідження й доведено, що існує проблема ідентифікації тієї чи іншої інновації з точки зору її ступеня інноваційності. Окреслено, проаналізовано ряд розбіжностей у науковій літературі щодо базових концепцій розуміння інновацій з високим рівнем інноваційності. Глибинно проаналізувавши ключові характеристики та риси кожного ступеню інновації, запропоновано найбільш повне та розширене визначення інкрементної, напів-радикальної, радикальної, проривної та руйнівної інновацій, а також створено матрицю інновацій для наочної демонстрації наявних характерних відмінних особливостей кожного окремого рівня інновації. Це глибинне дослідження сприяє теоретичному аналізу впливу інноваційних знань, а також розширює попередньо опубліковану наукову літературу, аналізуючи ії вплив на розуміння типів та ступенів інновацій, а також наявних взаємозв 'язків, характеристик та ключових відмінностей між ними. Результатами дослідження є підкріплена науковою літературою концептуальна база для сучасного розуміння термінології усфері інноваційної діяльності.

Key words: innovation, radical, incremental, disruptive, breakthrough.

Ключові слова: інновація, радикальна інновація, інкрементна інновація, руйніВна інновація, прориВна інновація.

\section{PROBLEM STATEMENT}

Today, there is a considerable amount of different innovation types: incremental, process, red ocean, service, business model, sustainable, blue ocean, radical, disruptive, supply chain, market pull, organizational, social and many others. While in terms of innovation direction there are clear delineation of types, there is some uncertainty in the levels (degrees) of innovation. For many years, there have been many disagreements in the scientific literature, which has significantly influenced both the level of an in-depth understanding of the concept of innovation and the quality of approaches to the evaluation of the innovation degrees. Since the scientific approach is valued in the modern world, it is obliged to give a clear and unambiguous interpretation of particular concepts.

\section{RECENT RESEARCHES}

\section{AND PUBLICATIONS ANALYSIS}

The following scientists and researchers made a significant contribution to the analysis of innovation degrees as well as their concepts in studies: W. Abernathy, P. Anderson, M. Assink, D. Audretsch, C. Christensen, K. Clark, M. Coccia, T. Davila, J. Fahey, C. Freeman, R. Garcia, H. Gatignon, R. Henderson, N. Kanagal, A. King, J. Lee, R. Leifer, F. Lettice, L. Morris, B, Nagji, D. Norman, K. Picaud, M. Raynor, P. Thomond, G. Tuff, M. Tushman, J. Utterback and others. Exploring different areas of innovation, the impact of innovation on economic development, researchers developed, improved and multiplied research papers in the field of innovation.

The purpose of the paper is to in-depth review the literature on innovation types to identify approaches that emphasize the degree of innovation and, to found and describe contradictory conclusions and arguments, and improve innovation theory by defining innovation levels for an accurate understanding of the essence of this area.

\section{INTRODUCTION}

Since Schumpeter's investigations, there has been a lot of research on innovations, their impact on the economic development as well as the causes and consequences of innovation creation and implementation. At the same time, there were studies that suggested a different typology, using different approaches and methods.

Researchers have suggested many classifications of innovation in the entire history of scientific research. Some researchers considered innovation based on the objective of innovation adoption thus separated them into administrative and technical categories. Some divided innovation into three classification based on the performance measures: rational plan, communication web, and disciplined problem solving. Based on innovation's effect on a firm's competencies, researchers in terms of typology distinguished competence enhancing and competence destroying types of innovation. Others analyzed basically radical and incremental innovation types based on the extent of change to technology [11]. The last classification, radical - incremental innovations, has received much attention from researchers who are interested in organizational learning and dynamic capability.

Abernathy \& Clark studied the following types of innovations: niche creation, architectural, regular, revolutionary [1]. Henderson \& Clark distinguish incremental, modular, architectural, and radical innovations [15]. Some researchers in their investigations just combine all highly innovative products to radical category.

So, the terms as incremental, radical, discontinuous, breakthrough, disruptive and really new are used ubiquitously to identify and evaluate different innovations. The question arises: what is the difference between these different classifications, innovation types and degrees? It is worthwhile to consider in depth the train of researchers thought in the field of innovation typology. 


\section{LITERATURE REVIEW}

The capacity to innovate is a central and enduring research theme for academics, which for over 80 years have been defining, explaining and measuring innovation in its many forms [9]. In parallel with the definition of innovation, an understanding of innovation activity goals and outputs, the importance and necessity of such activities, researchers delved into its typology.

Many researchers do not clearly define the specific types of innovation, but their logic can be traced by analyzing the definition of innovation as such. (Brown and Eisenhardt, Derting, Bish, It, Polder, Ettlie, Reza, Noori, Kanagal, Bohnsack, Wang, Markides, Laursen and Salter, Leiponen and Helfat etc.) understand the innovation, first of all, as a product, while (Hauschildt, Kotler and de Bes, Littkemann, Porter, Rogers, Valenta, Witfield, Reichstein, Terjesen and Patel etc.) tended to think that innovation is still a process. There were those who insisted that innovation may be both in product and process type (Schumpeter, Utterback and Abernathy, Slappendel, Damanpour, Dodgson and many others).

Joseph Schumpeter in the early 20th century expressed the idea that innovation is the carrying out of a new organisation of industry, such as the creation or destruction of a market monopoly. Later he proposed a list of various types of innovations, including: the introduction of a new product or a qualitative change in an existing product; process innovation new to an industry; the opening of a new market; development of new sources of supply for raw materials or other inputs; and changes in industrial organization [24].

In addition to product and process innovation there are some other types which also have an impact on the development of scientific research. According to [25] there are five types of innovation: business, product, process, marketing and service innovation. Previously the organizational innovation was also investigated, which involves the creation or alteration of business structures, practices, and models, and may therefore include process, marketing and business model innovation. Adding to this list the supply chain innovation, which mean the innovations that occur in the sourcing of input products from suppliers and the delivery of output products to customers, we define that innovation inherently appeared an important component of any business activity.

The Oslo Manual, the foremost international guide for the collection and use of data on innovation activities, for measuring innovation defines four types of innovation: product and process, which related to technological innovations as well as marketing and organizational, related to non-technological innovation [21].

Another distinguishing element in innovation types identification is the degree of innovation, which determines what kind of innovation comes out. Using this approach, Schumpeter systematizes his knowledge of innovation and proposes to consider the level of innovation on the line 'incremental - radical' degree of innovation, where incremental type means low degree of innovation and radical - high level. In Schumpeter's words, 'radical' innovations shape big changes in the world, whereas 'incremental' innovations fill in the process of change continuously. Radical innovations play a key role in economic development in Schumpeter's theory: 'Innovation is at the heart of economic change' [24].

Categorizing various types of technical change Freeman, Clark, \& Soete distinguish four types of innovation. According to the authors, incremental innovation is the result of inventions and improvements offered by engineers and others directly involved in the production process, or as a result of user initiatives and suggestions which do not suggest formal research and development activity [13]. Radical innovation is 'big improvements in the cost and quality of existing products' and is the result of a deliberate research and development activity in enterprises and /or in university and government laboratories. The technically and economically inter-related radical and incremental innovations in both products and processes authors understand as new technological systems. Researchers name technological revolution as the most influential and large-scale innovation type which leads to changes of techno-economic paradigm. It is far-reaching and pervasive changes in technology, affecting many (or even all) branches of the economy, as well as giving rise to entirely new sectors [13].

Abernathy \& Clark represent four kind of innovation, evaluating the market and technology transiliences. According to authors, niche creation type of innovation defines the effect on production and technical systems by conserve and strengthen established designs. Architectural innovation defines the basic product and process configuration and sets technical and marketing agendas that will contribute to further development. Regular or incremental innovation type involves change that builds on established production and technical competence and that is applied to existing markets and customers [1]. Focusing on revolutionary type of innovation, the authors define it as 'innovation that disrupts and renders established technical and production competence obsolete, yet is applied to existing markets and customers' [1;9, p. 12].

In 1990, Henderson and Clark demonstrate that the traditional categorization of innovation as either incremental or radical is incomplete and potentially misleading. They described an innovation typology that was based on an innovation's impact on core design components and relationships between them [15]. According to the authors, incremental type of innovation introduces quality improvements in core components. The authors associate incremental innovation with the word 'renovation'. Radical innovation, in turn, introduces a new meaning, potentially a paradigm shift, while modular innovation may result in the complete redesign of core components, leaving linkages between the components unchanged. They also add modular innovation, which changes a core design concept without changing the product architecture. Focusing on the architectural innovation concept, Henderson and Clark argue that 'architectural innovation is designed to draw attention to innovations that use many existing core design concepts in a new architecture and that therefore have a more significant impact on the relationships between components than on the technologies of the components themselves' [15, p. 14-15]. 
Valenta, defining novelty levels as dimensions characterizing innovation, distinguishes eleven innovation levels, one of which is negative (degeneration) [28]. The remaining 10 are regeneration, intensity, reorganization, change in quantity, qualitative adaptation, new variant, concept change, new species, new kind, new steam show the innovativeness level of the innovation from the least influential on the development of innovation, to entering new markets and revolutionary methods, as well as changes in consumer demand and consciousness.

Later VIcek divided levels proposed by Valenta into the 3 groups: rationalization, incremental, and radical innovations, while leaving all the levels that means agreement with the author on the above types of innovation [30]. In fact, the aspiration of authors to expand the degree and levels of innovation is reduced to nothing.

Langdon Morris used another approach to understand the innovation types. He provides four different types of innovations. The author described the modifications to existing products and services that improve functionality, reduce cost, or even change appearance just for fashion's sake as incremental innovations. The significant or radical departures from whatever's already available in the market Morris named product \& technology breakthrough. The author notes that 'they are sometimes referred to as 'discontinuous innovations' or 'rupture innovations,' because they disrupt the marketplace, which is the desired effect, or because they disrupt the organization that comes up with them, which is usually not the goal' [19, p. 30].

Because 'the key is not new technology, but rather new experiences delivered by new forms of organization', the author defined new methods to deliver products and services for customers as a third innovation type and named it business model innovations [19, p. 33]. Enlarging a company's scope of operations into markets that are so different from its current markets that they must be addressed by entirely new entities, new ventures is the most radical innovation type, provided by Morris. New ventures 'constitutes a distinct category because the creation of a new venture is an organizational response to innovation, a journey into new territory where new skills, perspectives, and indeed an entirely new identity are required' [19, p. 36]. Each of innovation types, presented above 'addresses a different aspect of the competitive situation - incremental innovations enable you to keep pace with the competition, while breakthroughs, new business models, and new ventures can put you significantly ahead' [19, p. 22].

Nagji \& Tuff argue that the best approach to innovation is to think in terms of managing an integrated, balanced 'portfolio' of innovation initiatives which are divided into three types: i) core or evolutionary innovation: line extension, refreshing or improving the performance of existing products, these innovations are incremental; ii) adjacent innovations which take the company into new business (without venturing too far from the core), by incrementally adding new products and assets; and iii) transformational or revolutionary innovations, which are not directly related to existing markets or technologies but represent totally new products or services which are not extensions of existing ones [20]. Those innovations are often described as breakthrough innovations, or discontinuous.
There is also an alternative, but less popular approach to degree of innovation, which is considering revolutionary and evolutionary innovation instead of radical and incremental ones. James Fahey designate that revolutionary innovation seeks to adapt the world to new ideas and it can quickly make available wondrous new products and services. On the other hand, it is disruptive and expensive, and it produces unpredictable outcomes. Evolutionary innovation seeks to adapt new ideas to the existing world, and it focuses on preserving or gradually changing existing fundamentals, including people, product, and business relationships [12]. However, his ideas were not further developed and only occasionally referred to as synonyms for certain levels of innovation.

Kanagal provide the approach, which distinguish different types of innovation depending on market type, where the innovation is creating (new or existing) and technologies, which is used to create innovation (new or existing). The definition of each type of innovation is formed by compiling technology and market characteristics. For example, 'If the innovation demonstrates radically new technologies and the differences are 'just noticeable' then it is called 'discontinuous innovation'. 'If the addition or extension/modification is a 'just noticeable difference' for existing markets and existing technologies is used, then it is called 'incremental innovation' or 'continuous innovation' [16, p. 5]. If the innovation has significant differences on existing markets, it is called the evolutionary innovation (using existing technologies) or substitute (radically new technologies). Using radically new technologies, the innovation named disruptive, if it creates new market with disruption of existing one, or revolutionary, if there is no disruption of existing market. Also, the author named value innovation or Blue ocean strategy those innovations, which going out to new competitive space no matter what kind of technologies it used.

Looking more closely at the extensive papers, it becomes clearer that researchers and scientists in the field of innovations and types of innovations look at 'innovation' as something that results from a successful technological and doing business changes. Davila in his Making Innovation Work wrote that to create innovation, successful companies combine technological changes and business model changes in their activity [11], let's understand these concepts and how they interact.

According to [11], innovation encompasses two established activities. The first of which is traditionally thought of as technological: research and development (R\&D), or new product development. The author indicates that technological change affects innovation in three different directions:

1. Product and Service Offerings. It is the most wellknown type of innovation, because the changes in the product or service that the company provides on the market (or the introduction of a completely new product or service) are primarily visible to consumers.

2. Process Technologies. Technologies are the integral part of product and services production. Improved, better and less expensive products and services are the result of changes in process technologies which are vital to the competitiveness of a new product. 


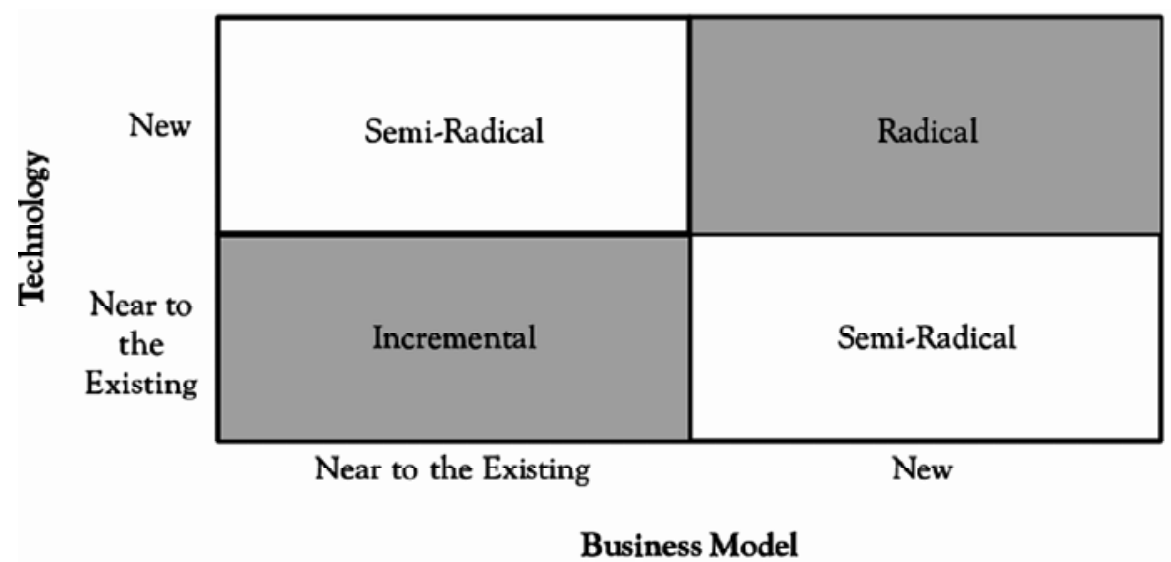

Fig. 1. Innovation Matrix with incremental, semi-radical, and radical innovation along the dimensions Technology and Business Model

Source: [11].

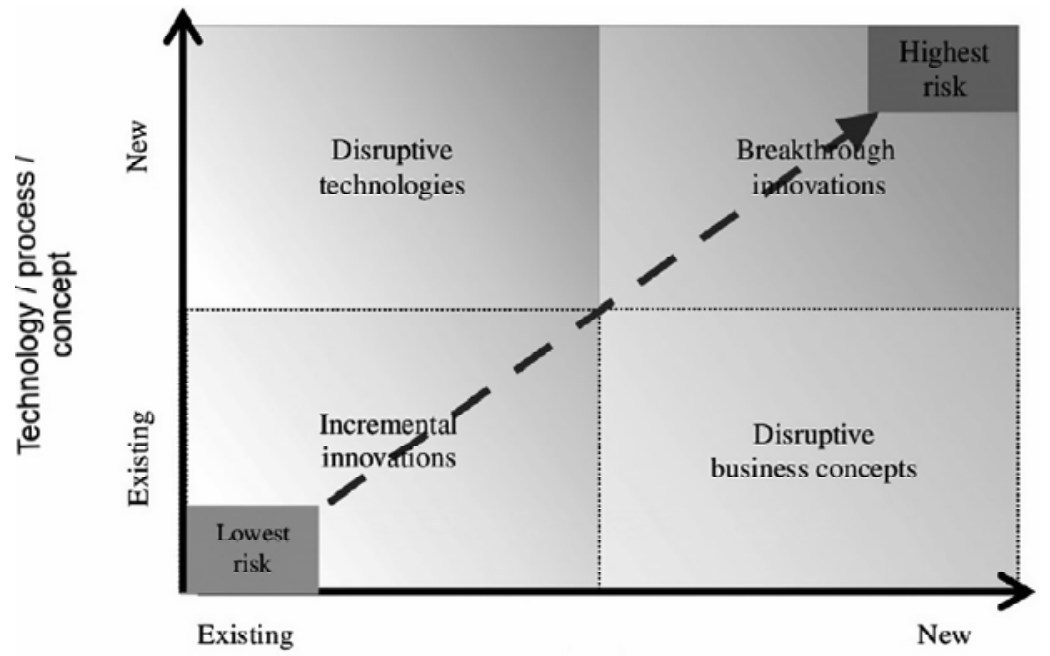

Market

Fig. 2. Innovation Matrix with incremental, disruptive, and breakthrough innovation

Source: [4].

3. Enabling Technologies, which help to develop technology solutions and improvements via research experiments which can revitalize the production system.

The second established activity is strategic: defining the business model. 'Business model is a framework for making money. It is the set of activities which a firm performs, how it performs them and when it performs them so as to offer its customers benefits, they want and to earn a profit' [3, p. 2]. Analyzing the business model changes as one of the main components in innovation creation and development, Davila defines three areas in which business model changes stimulate innovation [11]:

1. Value Proposition. Strategy is based on a differentiated customer value proposition. Satisfying customers is the source of sustainable value creation. This is essentially the change in WHAT is sold and supplied to the market.

2. Supply Chain. This type of business model change affects the value chain stages, including the way in which the company restricts, cooperates and functions to produce and deliver its goods and services This is essentially the change in $\mathrm{HOW}$ value is created and delivered to the market.
3. Target Customer. Expanding views on the target customers allows not only to expand sales, but also to enter new markets.

Later Davila designate that the business model describes how to create, sell and deliver value to end users. Analyzing technological and business-model changes, the authors mapped its relationship in structural innovation scheme with three types of innovation - Incremental, Semi-radical, and Radical.

Incremental type of innovation embraces existing technologies and business models; it leads to minor improvements in existing products delivered to existing markets using existing sales channels and business processes.

Semi-radical innovation, in turn, can make a decisive change in the competitive environment, which incremental innovation cannot do. Also, the author highlights the breakthrough technologies concept in term of semi-radical innovation (upper left on the Figure above) and defines it as semi-radical innovation type caused by a change in technology base. The author also notes that any semiradical innovation in business model or technology always 
requires some degree of change in another element. However, changes in one element (technological changes or business model changes) are more important for innovation success [11].

Radical innovation, in contrast, is a significant change that affects both the business process and the company's technology simultaneously. They bring fundamental changes to the industry' competitive environment [11].

Marnix Assink displayed a little differently the Innovation Matrix (Figure below).

According to Assink, Incremental innovation development remains within the boundaries of the existing market and technology or processes of an organization. Analyzing disruptive type of innovation, the author gives the definition, provided by Lettice and Thomond, who define it as 'a successfully exploited product, service or business model that significantly transforms the demand and needs of an existing market and disrupts its former key players' [26, p. 4].

Delving into the concept of disruptive innovation, Assink cite the Leifer's quotation: 'A radical innovation is a product, process or service with either unprecedented performance features or familiar features that offers significant improvements in performance or cost that transform existing markets or create new ones' [18]. Leifer, O'Connor, \& Rice thereby associates disruptive technologies and business concepts with radical innovation [18]. Learns a large volume of literature in the field of innovation, Assink gives his own definition of disruptive innovation, based mainly on Lettice \& Thomond's one: 'A successfully exploited radical new product, process, or concept that significantly transforms the demand and needs of an existing market or industry, disrupts its former key players and creates whole new business practices or markets with significant societal impact' [4, p. 221].

Breakthrough innovations are based on inventions that serve as a source of many subsequent inventions. Focusing more on disruptive innovation, Assink to some extent makes it clear that breakthrough innovations have similar characteristics and goals to disruptive one except a highly risk due to the long development time [4].

Let's make a short conclusion. Analyzing and systematizing profound knowledge in the field of innovation types, there are some inconsistencies in definitions as well as the possibility of using one or the other term for certain innovation. To understand this, we should delve into scientific work that does not provide such a systematic approach but emphasize something concrete that reveal the concept of a particular type of innovation. Let's start with the most new and young concept - the disruptive innovation.

Despite its popularity-in-use, the core concept of disruptive innovation remains widely misunderstood [7]. Many researchers, writers, and consultants use "disruptive innovation" to describe any situation in which an industry is shaken up and previously successful incumbents stumble. But that's much too broad a usage [8].

King \& Baatartogtokh define four key elements of the theory of disruptive innovation based on Christensen's theory [17]: i) incumbents in a market are improving along a trajectory of sustaining innovation. 'In every market there is a distinctly different trajectory of improvement that innovating companies provide as they introduce new and improved products.' ii) the pace of sustaining innovation overshoots customer needs, which is 'almost always outstrips the ability of customers in any given tier of the market to use it.' iii) incumbents have the capability to respond to disruptive threats but fail to exploit it. 'Disruption has a paralyzing effect on industry leaders.... they are constitutionally unable to respond' [7] iv) incumbents end up floundering as a result of the disruption. 'Performance oversupply opens the door for simpler, less expensive, and more convenient technologies to enter' [6].

Rafi define disruptive innovation as 'a technology, product or process that creeps up from below an existing business and threatens to displace it' [23]. Authors add that 'gradually, the new product or process improves to the point where it displaces the incumbent' [23].

Analyzing the emergence and impact of discontinuities, Veryzer claims that the perceived value attributes of a product or service are critical to discontinuous and disruptive innovation [29]. However, speaking of 'disruptive innovation', we should note that it is Clayton Christensen's theory, which he first introduced in 1997 in his 'The Innovator's Dilemma: When New Technologies Cause Great Firms to Fail'.

'Disruptive innovations are successfully exploited processes, technologies, products, services or business models that allow organizations to significantly change conventional competitive rules, thus transforming the demands and needs of existing markets' [14].

Marc Andreesen in his researches expects many industries to be disrupted by software, with new companies overtaking incumbents, but at the same time technology may enable the incumbents to radically transform their businesses, especially with new customercentric business models embedded in product-serviceecosystems.

Because Christensen's theory formed on 'classical' innovation types understanding, many researchers use 'radical innovation' and 'breakthrough innovation' as an alternative meaning of disruptive one, meanwhile equation of these terms is not obvious. Joseph Schumpeter looked at the world in terms of the possibility of its development: 'Revolutionary breakthroughs lie at the core of entrepreneurial activity and wealth creation' [24].

Dahlin \& Behrens argue that for an invention to be considered radical it has to fulfill three criteria: (i) the invention must be novel: it needs to be dissimilar from prior inventions; (ii) the invention must be unique: it needs to be dissimilar from current inventions; (iii) the invention must be adopted: it needs to influence the content of future inventions [10].

Thomond \& Lettice note that 'terms such as "disruptive", "radical", "non-linear", "discontinuous", "breakthrough", "paradigm-shifting" and "revolutionary" have all been used to describe what is in essence the opposite of sustaining innovations', accepting the idea that all that is new is no longer the sustaining innovation and no matter how it is called, indirectly equating these concepts, analyzing different types of innovation in terms of the final result instead of its characteristics [26]. 
Back to Nagji's and Tuff's approach, if the companies generate new business by either creating new products, markets or both, it is known as breakthrough innovation. The authors name it 'transformational area', which implies that companies transform themselves to make something new [20].

Christensen in passing argues that 'breakthrough innovations change an industry's competitive patterns' [8]. So, breakthrough innovation can be understood as a new and unique technological shift in the product category, which significantly changes the structure of consumption in the market.

Schumpeter's 'process of creative destruction' conceptually and literally began a radical revolution in economic theory. As Schumpeter wrote, entrepreneurs enter the market with commercial competitive advantages, that they not only compete but 'destroy' incumbent firms and their respective economies of scale due to the entrepreneur's superior innovation.

After Schumpeter's ideas some authors have come at radical innovation definition with many ways. Tushman \& Romanelli defined radical change as 'processes of reorientation wherein patterns of consistency are fundamentally reordered' [27].

Some researchers focused on risks and uncertainty investigating radical type of innovation because it differs by virtue of being inherently more complex and riskier than less radical types of innovations and typically require greater capital investment, at the same time with much more uncertain market responses.

Abernathy \& Clark focused on the result, therefore define radical innovation in terms of groundbreaking, discontinuous, disruptive changes in product, process, and technology [1].

A set of researchers (Dyer \& Singh, Galunic \& Eisenhardt, Lavie, Lewis at all) instead of radical innovation investigate 'discontinuous innovation'. Discontinuous type of innovation does not involve the development of radical new knowledge, therefore the application of existing knowledge in new fields, getting external knowledge to create new solutions by combining internal and external resources are crucial [22].

Some researchers (Anderson \& Tushman, Norling \& Statz) focus on narrower concept - the technological discontinuity - which is identified when an innovation pushes forward the performance frontier along the parameter of interest by a significant amount and does not by merely enlarging the scale of existing designs but changing the product or process design.

Researchers mostly look on discontinuous innovation as the reason for a new product totally different from the previous one. 'Discontinuous innovation is an innovation that is likely to create a new trajectory, face the challenge of having to move 'outside the box', beyond its prior experience' [5].

Picaud investigate different approaches to innovation types and conclude that 'where disruptive innovations are focus on changes in marketing discontinuities, radical innovations usually introducing radical technology creating new markets and potentially new industrial sectors' [22].

Picaud conclude that there are two dimensions to identify discontinuous innovation. 'Under technological development, discontinuous innovation is often characterized as competence destroying, or disruptive, and they are capable of bringing about major upheavals in the industries they impact. Under new product development, discontinuous innovation is often characterized as architectural: it changes the product configuration and combines components in new ways without introducing any fundamentally new component technologies' [22]. The author tried to figure out existing concepts in the field of innovation types and understand the logic researchers' thought. However, noted that there is a huge amount of definitions, Picaud simply add up the results of a set of articles, paraphrasing and simplifying its' main ideas.

In summary, there is an extensive literature distinguishing among different types of innovation. More novel innovations, named 'breakthrough' and 'disruptive' tend to be more novel and riskier than incremental innovations, which is simply called a change of something, in order to obtain well-defined benefits. Higher order effects causing profound organizational and market change, named 'radical innovation' arouses a special interest among researchers because of possible large-scale changes in the economic development.

Findings and Discussion. Based on scientific literature, the division of innovations into such types as incremental and radical attracted the researchers' interest for a long time. Incremental innovations represent the addition or refinement of existing technologies, products or other innovations. The need for such innovations is dictated by real life, market, or by economic, political, etc., conjuncture requirements. Such innovations are changing the world gradually, without leading to dramatic changes in technology, social life and the usual way of life of most people, especially does not affect customers' demand and consciousness.

Radical innovations, in contrast, significantly change the state of affairs in a particular area, and sometimes in many areas of human life simultaneously. It of ten requires a thorough restructuring or a change in the already existing models of the functioning of technical and social systems, the conditions of human life and management methods. Radical type of innovation often arises in periods of crises or significant socio-economic pressure, when major problems or conflicts can be resolved only in a 'revolutionary' way. Radical innovations in most cases are initiated by serious scientific developments and contribute to sharp jumps in scientific and technical progress and $R \& D$ development.

However, there are several concepts, which relate to serious and significant innovations - radical, disruptive, discontinuous, and breakthrough, - are the best examples. Many of these terms were defined quite a long time ago that allowed to create an incredible amount of scientific work that use, disclose, analyze, adapt and extend these concepts. A set of terms and its definitions related to degree of innovation are described in Table 1.

In summary, researchers write about innovation with radical, disruptive, breakthrough, and discontinuous characteristics. All characteristics have different impact of industries and the companies within it. However, there is no clear hierarchy of these concepts in scientific literature as well as understanding of what is more global, 
Table 1. Innovation Degrees Literature Review

\begin{tabular}{|c|c|}
\hline Author(s) & Main points and definitions \\
\hline \multicolumn{2}{|r|}{ Incremental Innovation } \\
\hline Freeman, Clark, \& Soete, 1982 [13] & $\begin{array}{l}\text { A result of inventions and improvements offered by engineers and others directly involved in the production } \\
\text { process, or as a result of user initiatives and suggestions which do not suggest formal research and } \\
\text { development activity }\end{array}$ \\
\hline $\begin{array}{l}\text { Abernathy \& Clark, } 1985[1] \\
\text { Abrunhosa \& Sá, } 2008[2]\end{array}$ & $\begin{array}{l}\text { Change that builds on established production and technical competence and that is applied to existing markets } \\
\text { and customers }\end{array}$ \\
\hline Henderson \& Clark, 1990 [15] & Incremental type of innovation introduces quality improvements in core components \\
\hline Davila, Epstein, \& Shelton, 2006 [11] & $\begin{array}{l}\text { Embraces existing technologies and business models; it leads to minor improvements in existing products } \\
\text { delivered to existing markets using existing sales channels and business processes }\end{array}$ \\
\hline Assink, 2006 [4] & $\begin{array}{l}\text { Incremental innovation development remains within the boundaries of the existing market and technology or } \\
\text { processes of an organization }\end{array}$ \\
\hline Morris, 2011 [19] & $\begin{array}{l}\text { The modifications to existing products and services that improve functionality, reduce cost, or even change } \\
\text { appearance just for fashion's sake }\end{array}$ \\
\hline Nagji \& Tuff, 2012 [20] & Named as Core innovation it is a line extension, refreshing or improving the performance of existing products \\
\hline \multicolumn{2}{|r|}{ Radical Innovation } \\
\hline Schumpeter J., 1942 [24] & $\begin{array}{l}\text { Radical innovation results in 'gales of creative destruction' that wipe away the old while creating new } \\
\text { opportunities }\end{array}$ \\
\hline Freeman, Clark, \& Soete, 1982 [13] & Name radical innovation as 'big improvements in the cost and quality of existing products' \\
\hline Tushman \& Romanelli, 1985 [27] & Radical change is a process of reorientation wherein patterns of consistency are fundamentally reordered \\
\hline Henderson \& Clark, 1990 [15] & Radical innovation introduces a new meaning, potentially a paradigm shift \\
\hline $\begin{array}{l}\text { Leifer, O'Connor, \& Rice, } 2001[18] \\
\text { Picaud, } 2013 \text { [22] }\end{array}$ & $\begin{array}{l}\text { A radical innovation is a product, process or service with either unprecedented performance features or } \\
\text { familiar features that offers significant improvements in performance or cost that transform existing markets or } \\
\text { create new ones. Radical innovations often imply changes that have a significant impact on a market }\end{array}$ \\
\hline Davila, Epstein, \& Shelton, 2006 [11] & $\begin{array}{l}\text { Radical innovation is a significant change that affects both the business process and the company's technology } \\
\text { simultaneously. They bring fundamental changes to the industry' competitive environment }\end{array}$ \\
\hline Abrunhosa \& Sá, 2008 [2] & 'If the innovation challenges the dominant practices and knowledge, then it can be considered as radical' \\
\hline \multicolumn{2}{|r|}{ Disruptive Innovation } \\
\hline Christensen C., 1997 [6] & $\begin{array}{l}\text { Defines disruptive innovations as those in which incumbent firms lose out in the post-innovation competition, } \\
\text { conflating cause and effect. It is a technological change that introduces a product whose performance is } \\
\text { measured in new ways }\end{array}$ \\
\hline Hamel, 2000 [14] & $\begin{array}{l}\text { Disruptive innovations are successfully exploited processes, technologies, products, services or business } \\
\text { models that allow organizations to significantly change conventional competitive rules, thus transforming the } \\
\text { demands and needs of existing markets }\end{array}$ \\
\hline $\begin{array}{l}\text { Thomond \& Lettice, } 2002[26] \\
\text { Assink, } 2006[4]\end{array}$ & $\begin{array}{l}\text { A successfully exploited radical new product, process, or concept that significantly transforms the demand and } \\
\text { needs of an existing market or industry, disrupts its former key players and creates whole new business } \\
\text { practices or markets with significant societal impact }\end{array}$ \\
\hline Rafi \& Kampas, 2002 [23] & A technology, product or process that creeps up from below an existing business and threatens to displace it \\
\hline Christensen \& Raynor, 2003 [7] & $\begin{array}{l}\text { The new product is de-rated regarding the primary performance dimension most appreciated by mainstream } \\
\text { customers of the old product. However, perform better on an alternate dimension and thus open a new market }\end{array}$ \\
\hline Kanagal, 2015 [16] & Creating radically new technologies combined with disruption of existing markets \\
\hline \multicolumn{2}{|r|}{ Breakthrough Innovation } \\
\hline Davila, Epstein, \& Shelton, 2006 [11] & $\begin{array}{l}\text { For breakthrough innovations changes in the technological landscape are often associated with new paradigms } \\
\text { or new dominant designs }\end{array}$ \\
\hline Assink, $2006[4]$ & $\begin{array}{l}\text { Breakthrough innovations have similar characteristics and goals to disruptive one except a highly risk due to } \\
\text { the long development time }\end{array}$ \\
\hline Nagji \& Tuff, 2012 [20] & $\begin{array}{l}\text { Represent totally new products or services which are not extensions of existing markets and technologies. The } \\
\text { author names it 'discontinuous' and 'revolutionary' innovations }\end{array}$ \\
\hline $\begin{array}{l}\text { Christensen, Altman, McDonald, \& } \\
\text { Palmer, } 2016 \text { [8] }\end{array}$ & Breakthrough innovations change an industry’s competitive patterns \\
\hline \multicolumn{2}{|r|}{ Discontinuous Innovation } \\
\hline Veryzer, 1998 [29] & $\begin{array}{l}\text { Discontinuous innovation involves capabilities that do not exist in current products and cannot be achieved } \\
\text { through extensions based on existing technologies }\end{array}$ \\
\hline $\begin{array}{l}\text { Bessant, Von Stamm, Moeslein, \& } \\
\text { Neyer, } 2010 \text { [5] }\end{array}$ & $\begin{array}{l}\text { Discontinuous innovation is an innovation that is likely to create a new trajectory, face the challenge of having } \\
\text { to move 'outside the box', beyond its prior experience }\end{array}$ \\
\hline Picaud, $2013[22]$ & $\begin{array}{l}\text { Discontinuous innovations are capable of bringing about major upheavals in the industries they impact. It } \\
\text { changes the product configuration and combines components in new ways without introducing any } \\
\text { fundamentally new component technologies }\end{array}$ \\
\hline Kanagal, 2015 [16] & $\begin{array}{l}\text { If the innovation demonstrates radically new technologies and the differences are 'just noticeable' then it is } \\
\text { called 'discontinuous innovation' }\end{array}$ \\
\hline Financial Times lexicon & $\begin{array}{l}\text { Discontinuous innovation refers to the development or application of new technologies, concepts or ideas. } \\
\text { They cause a paradigm shift in science or technology and/or the market structure of an industry }\end{array}$ \\
\hline
\end{tabular}

Source: created by authors.

what is characteristic of the other, and what has limited impact.

Having conducted in-depth analysis of the innovation typology development, key concepts and definitions by vast number of researchers, we define the following mismatches and inconsistencies:

1. A fairly wide range of definitions for each type of innovation. Researchers analyze terms through the prism of already written articles often without bringing new meaning but simply rearranging the words in places and replacing them with synonyms. Others expand existing definitions by adding more appropriate and accurate words. The result is a huge number of definitions, which have the same logic.

2. There is no clear understanding of the difference between radical, disruptive, breakthrough, and discontinuous innovations. Authors such as $[1 ; 15 ; 4 ; 11 ; 20 ; 16]$ presents its innovation typology based on different 


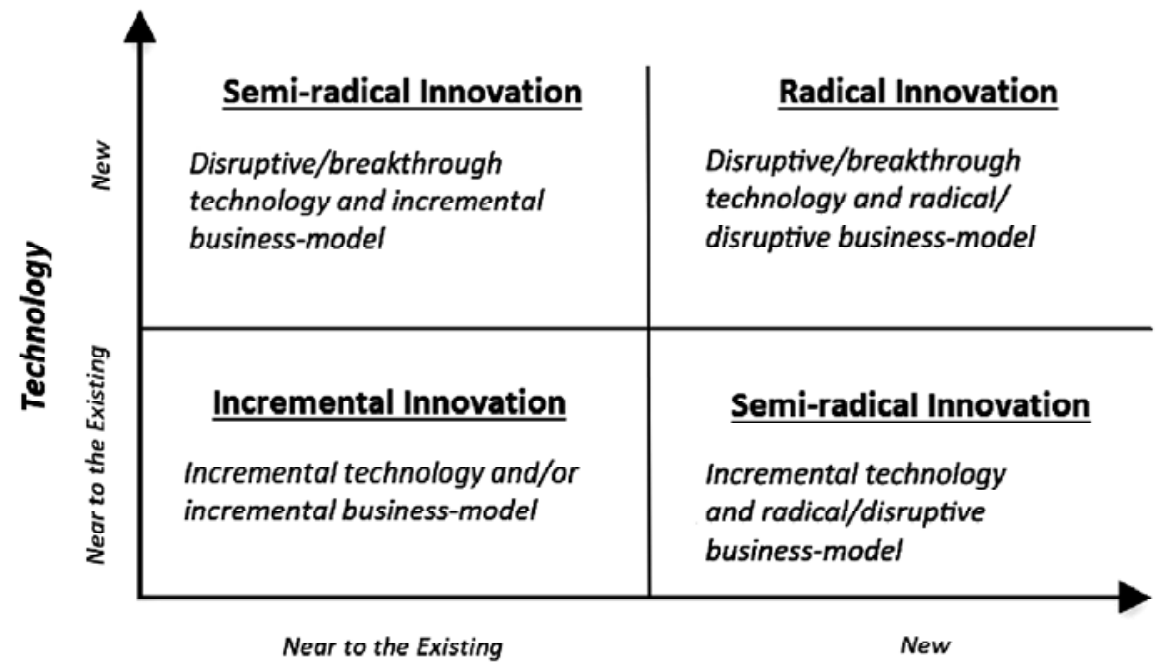

Business-model

Source: created by authors.

Fig. 3. Degree of innovation matrix

approaches and literature review. As we find in previous chapter, researchers of ten cite others with the distortion of the term itself calling a radical innovation, for example, as discontinuous that means no differences between these terms.

3. Incomprehensible relationship between different degrees of innovation. If the innovation is radical by its characteristics according to Davila, can it be a discontinuous? Breakthrough? Picaud based on 7 different studies, tried to find interrelation between types of innovation, but the author limited herself to only level of novelty for the market and firm as well as characterization of technology used to create innovation [22].

Based on extensive studies in the field of innovation, we define innovation degrees as follows:

Incremental or evolutionary innovation is the refreshing, improving the performance, and modification of existing product, services, and methods, which affects either the business process or the company's technology or both and remains within the boundaries of the existing market and technology or processes of an organization.

Semi-radical innovation is a significant change that involves substantial change in either technology (technological-centered innovation) or its business model (business-model-centered innovation), but not to both. In the first instance innovation is characterized by disruptive or breakthrough technology and incremental businessmodel innovation, in the second - by incremental technology and disruptive or radical business-model innovation.

Disruptive innovation is a creating radically new technologies introduces a product whose performance is measured in new ways, which leads to transforming the demands and needs of existing markets in a disruptive manner as well as open a new market changing conventional competitive rules. It is also a business model, a completely different system of values, a portfolio of new partners, suppliers and new ways of entering the market in which the product or service is offered.

Breakthrough innovation is a totally new and unique technological shift in the product, service, or method category, which are not extensions of existing markets and technologies and leads to significant changes in the structure of consumption in the market as well as industry's competitive patterns but does not disrupt existing markets and its incumbents.

Radical or discontinuous innovation is a significant change, new meaning or paradigm shift that affects both the business process (in radical or disruptive manner) and the company's technology (in breakthrough or disruptive manner) simultaneously and leads to transforming existing markets, changing its structure as well as creating new markets and potentially new industrial sectors.

Revolutionary innovation means either semi-radical or radical innovation.

Figure below represents innovation degrees in the form of a matrix.

Based on this classification matrix, there are $11 \mathrm{com}$ binations of technology and business-model levels to create 4 different innovations with radical, semi-radical, and incremental degrees of innovation.

\section{CONCLUSION}

Nowadays, innovations are one of the most important forms of expanding the capabilities and competitiveness of the economic system in the modern world. Over the last hundred years, many papers have been written on the topic of innovations and their influence on the development of mankind. Notwithstanding, innovation types raise many questions especially when assessing them in terms of innovation degree.

Our research contributes to the theoretical analysis of the impact of the innovation knowledge and extends the previous literature by analyzing its effect on understanding the degree of innovation as well as its interrelationships. Firstly, we found extensive number of innovation degree definitions from the lowest level (incremental innovation type) to the highest (radical innovation type), analyzed them and systemized researcher's knowledge and investigations in the field of innovation types. Next, we examined depth articles that 
bring new knowledge to the innovativeness levels and made the consistent train of innovation types thought.

Wide range of scientific papers quite often twists the terms and equates different innovation degrees concepts especially revolutionary ones (radical, disruptive, discontinuous, and breakthrough). Distinguishing these concepts, we created some awareness around innovation typology by defining each degree of innovation based on in-depth literature review, thereby giving the pivot to subsequent researchers that will help to interpret degrees of innovation correctly.

This paper is intended as a contribution towards the examination of the main taxonomy in the scientific literature containing the innovation subject. We offered a fresh look at the problem of interpretation and use of base concepts by creating the degree of innovation matrix of a relationship between high degrees of innovation. Affecting all degrees of innovation, our degree of innovation matrix most accurately shows the relationship between different innovations allowing researchers look wider and more globally on differences between main concepts in the sphere of innovation.

\section{References:}

1. Abernathy, W. and Clark, K. (1985), "Innovation: Mapping the winds of creative destruction", Research Policy, vol. 14, pp. 3-22.

2. Abrunhosa, A. and Sa, P. (2008), "Are TQM principles supporting innovation in the Portuguese footwear industry?", Technovation, vol. 28, pp. 208-221.

3. Afuah, A. (2002), Innovation Management: Strategies, Implementation, and Profits, 2nd ed., Oxford University Press.

4. Assink, M. (2006), "Inhibitors of disruptive innovation capability: a conceptual model", European Journal of Innovation Management, vol. 9, pp. 215-233.

5. Bessant, J. Von Stamm, B. Moeslein, K. and Neyer, A.-K. (2010), "Backing outsiders: selection strategies for discontinuous innovation", R\&D Management, vol. 40 , pp. $345-356$.

6. Christensen, C. (1997), The Innovator's Dilemma: When New Technologies Cause Great Firms to Fail, Harvard Business School Press, Boston, MA.

7. Christensen, C. and Raynor, M. (2003), The innovator's solution: creating and sustaining successful growth, Harvard Business School Press., Boston, MA.

8. Christensen, C. Altman, E. McDonald, R. and Palmer, J. (2016), Disruptive Innovation: Intellectual History and Future Paths, Harvard Business School, Boston, MA.

9. Coccia, M. (2006), "Classifications of Innovations Survey and Future Directions", Ceris-Cnr, W.P. N ${ }^{\circ}$, pp. $7-$ 19.

10. Dahlin, K. and Behrens, D. (2005), "When Is an Invention Really Radical? Defining and Measuring Technological Radicalness", Research Policy, vol. 34, pp. 717-737.

11. Davila, T. Epstein, M. and Shelton, R. (2006), Making Innovation Work: How to Manage It, Measure It, and Profit from lt, 3rd ed., Wharton Publishing.

12. Fahey, J. (2013). Revolution vs Evolution in Innovation. Retrieved from James Fahey, International
Business and Technology Innovation, available at: http:/ /www.jamesfahey.com/2013/05/03/revolution-vsevolution / (Accessed 3 May, 2013).

13. Freeman, C. Clark, J. and Soete, L. (1982), Unemployment and Technical Innovation: A Study of Long Waves and Economic Development, Frances Printer, London.

14. Hamel, G. (2000), Leading the Revolution, Harvard Business School Press., Boston, MA.

15. Henderson, R. and Clark, K. (1990), "Architectural Innovation: The Reconfiguration of Existing Product Technologies and the Failure of Established Firms", Administrative Science Quarterly, vol. 35, pp. 9-30.

16. Kanagal, N. (2015), "Innovation and product innovation in marketing strategy", Journal of Management and Marketing Research, vol. 18, pp. 1-25.

17. King, A. and Baatartogtokh, B. (2015), "How Useful is the Theory of Disruptive Innovation?", MIT Sloan Management Review, vol. 19, pp. 1-16.

18. Leifer, R. O'Connor, G. and Rice, M. (2001), "Implementing radical innovation in mature firms: the role of hubs", The Academy of Management Executive, vol. 15, pp. $102-123$.

19. Morris, L. (2011), Permanent Innovation, Revised Edition: Proven Strategies and Methods of Successful Innovators, Innovation Academy.

20. Nagji, B. and Tuff, G. (2012), "Managing your Innovation Portfolio", Harvard Business Review, pp. 6674.

21. Organisation for Economic Co-operation and Development (2005), Oslo Manual: Guidelines for Collecting and Interpreting Innovation Data, 3rd ed., OECD.

22. Picaud, K. (2013), "Discontinuous Innovation (DI): A review of definitions, theoretical perspectives and measures - towards an empirical study of the role of the purchasing department in DI", ESSCA School of Management, Angers.

23. Rafi, F. and Kampas, P. (2002), "How to identify your enemies before they destroy you", Harvard Business Review, vol. 80, pp. 115-123.

24. Schumpeter, J. (1942), Capitalism, Socialism and Democracy, Harper and Brothers.

25. Siegemund, C. (2008), Blue Ocean Strategy for small and mid-sized companies in Germany, Diplomica Verlag GmbH., Hamburg.

26. Thomond, P. and Lettice, F. (2002), "Disruptive Innovation Explored", 9th IPSE International Conference on Concurrent Engineering: Research and Applications. Cranfield University, Cranfield, UK.

27. Tushman, M. and Romanelli, E. (1985), "Organizational Evolution: A Metamorphosis Model of Convergence and Reorientation", Research in Organizational Behavior, vol. 7, pp. 171-222.

28. Valenta, F. (2001), Inovace $v$ manazerske praxis, Velryba, Prague.

29. Veryzer, R. (1998), "Discontinuous Innovation and the New Product Development Process", Journal of Product Innovation Management, vol. 15, pp. 304-321.

30. VIcek, R. (2011), Strategie hodnotovych inovaci: tvorba, rozvoj a meritelnost inovaci. Professional Publishing, Prague.

Стаття надійшла до редакцї 29.05.2019 p. 